\title{
Erratum to: Interaction between climate and management on beta diversity components of vegetation in relation to soil properties in arid and semi-arid oak forests, Iran
}

\author{
Mehdi HEYDARI ${ }^{1 *}$, Fatemeh AAZAMI ${ }^{1}$, Marzban FARAMARZI ${ }^{2}$, Reza OMIDIPOUR ${ }^{3}$, \\ Masoud BAZGIR ${ }^{4}$, David POTHIER ${ }^{5}$, Bernard PRÉVOSTO ${ }^{6}$ \\ ${ }^{1}$ Department of Forest Science, College of Agriculture, Ilam University, Ilam 6939177111, Iran; \\ ${ }^{2}$ Department of Rangeland and Watershed Management, College of Agriculture, Ilam University, Ilam 6939177111, Iran; \\ ${ }^{3}$ Department of Rangeland and Watershed Management, College of Natural Resources and Earth Sciences, Shahrekord \\ University, Shahrekord 14536-33143, Iran; \\ ${ }^{4}$ Department of Soil Science, College of Agriculture, Ilam University, Ilam 6939177111, Iran; \\ ${ }^{5}$ Department of Wood and Forest Sciences, Centre for Forest Research, Laval University, Quebec, QC G1V 0A6, Canada; \\ ${ }^{6}$ Irstea-National Research Institute of Science and Technology for Environment and Agriculture, Aix-en-Provence 13128, \\ France
}

Published online: 04 January 2019

(C) Xinjiang Institute of Ecology and Geography, Chinese Academy of Sciences, Science Press and Springer-Verlag GmbH Germany, part of Springer Nature 2019

Erratum to: J Arid Land (2019) 11(1): 43-57

doi: https://doi.org/10.1007/s40333-018-0024-z

In this Erratum, we correct the order of the first name and the last name of all authors in Journal of Arid Land and the correction is as follows: Mehdi HEYDARI, Fatemeh AAZAMI, Marzban FARAMARZI, Reza OMIDIPOUR, Masoud BAZGIR, David POTHIER, Bernard PRÉVOSTO.

The online version of the original article can be found under doi: https://doi.org/10.1007/s40333-018-0024-z 